\title{
Comparative botanical studies on some lamiaceous plants in Egypt.
}

Khalil, A. B. I.; Moussa, A. A.A and Bakr, A.M.A.

Dept. of Agri. Bot., Faculty of Agri., Al-Azhar univ. , Cairo, Egypt.

\begin{abstract}
This study is conducted on 8 genera belonging to Lamiaceae. The samples are collected from different areas in Egypt. The study is done on the morphological characters of roots, stems, leaves or leaflets, flowers, inflorescences and fruits. Also the anatomical characters of roots, stems and leaves are studied. The results are recorded in the form of comparison among the examined plants. Most of the examined plants are herbs as inMoluccellalaevis butVitexagnus - castusisshrub and Tectoniagrandisis tree. The aerial stems are present in all examined plants, while the rhizomatous subterranean stems are present in Menthapiprata. The anatomical study shows that theoutline shape of cross section is 4- angular in all stems of the examined plants except Teucriumpoliumis rounded
\end{abstract}

Key words: Morphology - Anatomy - Lamiaceae - Salvia - Mentha.

\section{Introduction}

Lamiaceae contains around 250 genera and 7000 species (Chakeret al 2011). Members of this family are useda medicinal, ornamental and aromatic plants. Lamiaceaeareperennial or annual herbs, shrubs and rarely trees Migahid and Hammouda (1974) and Watson and Dallwitz (1992).Lamiaceaehave taproots and fibrous adventitious roots Kotb (1985) and Baran and Ozdemir (2006). The stems areerect or rhizomes, branched, quadrangular, hairy and woody or herbaceous Kotb (1985) andBoulos (2002). The leaves are simple, hairy to glabrous,petiolate or sessile, decussate, exstipulate,ovate, lanceolate, obovate and oblong, lamina margins entire, crenate and serrate, the venation is reticulateTackholm (1974), Hickey and king (1981) and Celepet al (2011). Flowers of Lamiaceae are aggregated in inflorescences usually in verticils or in spikes or in panicles; terminal or axillary. The bracteoles are present or absent Watson and Dallwitz (1992). The calyx of Lamiaceae is 5 sepals, united into a campnulate or funnel form tube, sometimes 2- lipped, persistent in fruit Hickey and King (1981) and Waly and EL- gayed (2012). The corolla isbilabiate with 2 - lips or limb regular of 4almost equal lobes or bilabiate with only lower lip developed Tackholm (1974). The stamens of Lamiaceaeareusually 4 or 2, equal or unequal Watson and Dallwitz (1992). The gynoecium is usually consists of two united carpels, terminal or gynobasic style and a more or less deeply bifid stigma, equal or unequal. EL-Gazzar and Watson (1970) and Wendy (1994). The fruitis usually agroup of 4 nutlets, sometimes adroupe Hickey and King (1981). The cortex of the root isparenchymatousorparenchymatous and sclerenchmatous cells Akcin et al(2006)and Baran et al(2008). Stems in many genera are quadrangular in transverse section with groups of collenchyma in the 4 angles, collenchyma absent from the cortex in species and the vascular bundles are bigger in corner Metcalfeand Chalk(1950) and Akcin et al (2006).Ozdemir and Senel (1998) and Satil and Kaya(2007) discussed the anatomical features of the leaf of Lamiaceae.

Taxonomicaly,Cronquist (1981) mentioned that TectoniagrandisL. And Vitexagnus castusLinn.were belonged to theVerbanaceaebut Chaseet al (2003) recorded that TectoniagrandisL. And Vitexagnus - castusLinn. were belonging to the Lamiaceae according to morphological and chemical features.

The present investigation discusses the similarity of 8 genera belonging to Lamiaceae according to the morphological and anatomical characters of roots, stems and leaves or leaflets.

\section{Materials and Methods}

The samples are contained eight species belonging to eight genera of Lamiaceae collected from various regions in Egypt. The identification of the collected plants was achieved by comparing there morphological characters with the characters of previously identificated plants as published by Bailey (1951), Tackholm (1974), and Boulos (2002). Specimens from tested plants were fixed in (F.A.A) for a minimum period of 48 hours. Specimens were prepared according to Sass (1958).All photomicrographs were prepared by Pentacon Camera on Olympus microscope B H 2 and Stereomicroscope Carlzeiss Jena (Citoval 2). 
Table 1.Alphabetical list of (8) genera belonging toLamiaceae together with their sources. $\mathrm{S}=$ Santekatreen, $\mathrm{N}=$ Nasr city, N.C = North coastal and $\mathrm{D}=\mathrm{El}$ Doki

\begin{tabular}{llllll}
\hline NO. & Species & Sources & NO. & Species & Sources \\
\hline $1-$ & Coleus blumeiBenth. & N & $5-$ & Salvia farinaceaBenth. & N \\
2- & LavandulapubesansDecne. & S & $6-$ & TectoniagrandisL. & D \\
$3-$ & MenthapiprataL. & S & $7-$ & TeucriumpoliumL. & N.C \\
4- & Moluccellalaevis L. & N & $8-$ & Vitexagnus-castusLinn. & D \\
\hline
\end{tabular}

\begin{tabular}{|c|c|}
\hline Abbreviations & \\
\hline Aerenchyma........................... Ae. & Prismatic crystals ........................... \\
\hline Amorphous inclusions ................. Am. & Sclerenchyma tissue ...................... \\
\hline Cortex................................... Co. & Sclerenchyma sheath................... Sh. \\
\hline Epidermis................................. & Secretory cavities...................... Sk. \\
\hline Fiber sheth................................ & Secretory cells......................... Sc. \\
\hline Periderm............................. Pe. & Spongy tissue........................St. \\
\hline Lower epidermis....................... Le. & Tyloses...................... \\
\hline Palisade tissue............................ Pt. & Upper epidermis.........................Ue. \\
\hline 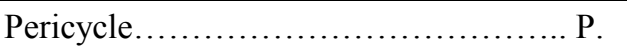 & Vascular bundle................................. Vb. \\
\hline Pith.................. & Xylem.............. \\
\hline
\end{tabular}

\section{Results and Discussion}

1-Morphological characters

Habit: The examined plants of Lamiaceaeare perennial herbs as in Menthapiprataor annual herbs as in Moluccellalaevisbut Vitexagnus castusisshrub, and Tectoniagrandisistree. These results are in agreement with those obtainned byMigahidand Hammouda (1974) andWatson and Dallwitz (1992) whorecorded that the plantsof Lamiaceae were annual or perennial herbs, shrubs and rarely trees.

Roots:The roots are mostly tap as in Salvia farinacea (Fig.1) while some taxa have adventitious fibrous root as inMenthapiprata(Fig.2) .Similar results are repoted by Kotb (1985) and Baran and Ozdemir (2006)who reported that the roots of Lamiaceae were tap and also have adventitious fibrous root.

Stem: The stem is aerial in all examined plants except in Menthapipratawhich has both aerial and rhizome stems (Fig.2). The stem is branched in all examined plants except in Moluccellalaevisis unbranched (Fig.3).These results are in agreement with those obtained by Kotb (1985) andBoulos (2002) who observed that the stem of Lamiaceae is erect or rhizomes, branched, quadrangular, hairy and woody or fleshy.

Leafor leaflets:The leaves or leaflets are exstipulate;opposite decussate in all the examined plants. The leaves are usually simple while Vitexagnus - castushas compound palmate leaves (Fig.4).The leaves or leaflets varies greatly in the shape, They are ovate as in Coleus blumei (Fig.5), lanceolate as inSalvia farinacea (Fig.6),palmetalylobed as in Moluccellalaevis (Fig.7),pinnately-loped as inLavandulapubesans(Fig.8).Lamina is green in the examined plantsexceptColeus blumei which hascolor leaves(Fig.5).The apex of the leaves or leaflets is acute in all the examined plantsexcept in Coleus blumei is obtuse (Fig.5). The venation is generally reticulate pinnate as in Coleus blumei(Fig. 5) and reticulate palmate as inMoluccellalaevis only(Fig.7). These results are in agreement with Tackholm (1974), Hickey and King (1981) and Celep et al (2011). who recorded that the lamiaceae of plants were the leaves. Simple (ovate, lanceolate,obovate), pinnately or palmately dissected and compound exstipulate, opposite, the venation was reticulate.

Flower and inflorescence:The flowers arehermaphrodite and petiolate in all examined plants exceptin Lavandulapubesanswhich has sessile flowers. Theinflorescences are terminal as in Lavandulapubesans(Fig.9),

butMoluccellalaevishasaxillaryinfloresc-

ences(Fig.3). The inflorescence usually are verticillate as inMoluccellalaevis (Fig.3) except inLavandulapubesansonly (Fig.9) which has simple spike and compound racemeas inTectoniagrandisonly(Fig.10). Such results are reported by Watson and Dallwitz (1992) and Yetisen(2014) who stated that theflowers ofLamiaceae were hermaphrodite and the inflorescence was verticilsusually. These terminal, or axillary, forming spikes, heads, racemes or panicles.

I- Calyx:Calyx consists of five sepals inthe investigated plants except in Tectoniagrandisare six sepals. The sepals are glabrous in mostly the investigated plants but some plants are hairy as inVitexagnus - castusThese results are in agreement withHickey and King (1981) and Waly and EL- 
gayed (2012)who observed that the calyx was glabrous or hairy.

II - Corolla:Corolla shape is bilabiate as in Salvia farinacea(Fig.11), 4 almost equal lobes as inMenthapiprata (Fig.12) and 6 almost equal lobes as in Tectoniagrandis(Fig.13). Corolla usually consists of five petals in all the investigated plants except inTectoniagrandisconsists of six petals (Fig.13).Corolla is glabrous in allinvestigated plants except in Salvia farinaceaishairy.Such results were strengthened by Tackholm (1974) Who pointed out that corolla,usually 5 petalsbilabiatae with 2 distnct lips or 4 almost equal lobes.

III - Androecium: The androecium consists of 4 stamens as inMoluccellalaevis(Fig.14), 2 stamens as in Salvia farinacea (Fig.15) and 6 stamens as in Tectoniagrandis(Fig. 13). The stamens in some examined plants are unequal as inMoluccellalaevis(Fig.14), but some other plants have equal stamens as inVitexagnus - castus.The filament glabrous in all examined plants but is hairy inMoluccellalaevis only.These results are in agreement with those obtained by Watson and Dallwitz (1992)who reported that the androecium was consisted 2 and 4 stamens, equal or unequal.

IV- Gynoecium:The gynoecium consists of 2 carpels in all of the examined plants. Thestigmais linear in all of the examined plants (Fig. 16) and in Lavandulapubesans onlycapitate (Fig.17), The styles are united in all the investigated plants, It is gynobasic in all of the examined plants as inMoluccellalaevis inTectoniagrandisandVitexagnus - castusitis terminal (Fig.19). The ovary shape oblong in all of the examined plantsexcept inTectoniagrandis and Vitexagnus - castusisrounded (Fig.19).It is glabrous in all of the examined plants except in Tectoniagrandis is hairy(Table 3). These results were in agreement with those obtained byEL-Gazzar and Watson (1970) and Wendy (1994). who recorded that the gynoecium was usually consists of two united carpels, terminal or gynobasic style and a more or less deeply bifid stigma, equal or unequal.

Fruit:The fruits are nutlets in all examined plants (Fig. 20) except inTectoniagrandis and Vitexagnus castusare droup(Fig.21).The fruits are in all examined plants persis-tent calyx. These results were in agreement with those obtained by Hickey and King (1981)andBadamtsetseg (2016). who observed that the fruit was usually group of 4 nutlets, sometimes adroupe, enclosed by the calyx.

\section{2 -Anatomical characters}

Root: The cortical layer consists of parenchymatous cells in most of examined plants as in Menthapiprata, but some plants have bothparenchymatousandscleraenchymotous cells as inTeucriumpolium (Fig.23), aerenchyma are noticed in the cortex ofMenthapiprataonly(Fig.24). Pericycleis consists of parenchymatous cells in mostlyof theexamined plants except in Salviafarinacea are have parenchymatous andscleraench-ymotous cells(Fig. 25). Tylosesare noticedin Coleusblumeionly (Fig.26).Similar results are reported Akcinet al(2006)and Baranet al(2008) who found that the cortex was parenchyma, aerenchyma or sclerenchma in Lamiaceae.

Stem: The stem varies in the external shape. It is 4angular in all the examined plants except Teucriumpoliumis rounded(Fig.27). Secretory cells are observed in some plants in the epidermal cells as in Teucriumpolium(Fig.27). Secretory cavities are observed in the cortex as inTeucriumpolium (Fig.28). Amorphous inclusions are present in the cortical cells inMoluccellalaevis (Fig.29).Pericycle is consist of parenchymatous cells in some observed plants as inMoluccellalaevis (Fig.29) and it is consist of sclerench-ymaatous and parenchymatous cells in other plants as in Salvia farinacea(Fig.30). Amorphous inclusions are present inMoluccellalaevis(Fig.29). The vascular bundle is bicollateral in some of examined plants as in Salvia farinacea(Fig.30).but it is collateral in some examined plants as in Moluccellalaevis (Fig.29).The main vascular bundle is present in corners in all of examined plants except in Teucriumpolium(Fig.27) is arranged in- rang shape.Tyloses are present in Tectoniagrandis(Fig.31). The stem is solid in all of taxa except inMoluccellalaevis(Fig.29)is hollow.This result is in agreement with Metcalfeand Chalk(1950) and Akcin et al (2006)the stems in many genera quadrangular in transverse section with groups of collenchyma in the 4 angles, collenchyma absent from the cortex in species and the vascular bundles were bigger in corners.

Leaf or leaflets: Secretory cells and amorphous inclusions are noticed in few the examined plants in epidermis as in Teucriumpolium (Fig.32) Secretory cells are shown only in Teucriumpoliumin mesophyll (Fig.32). Upper epidermis shape in the midrib region is concave in all of the examined plants except in Tectoniagrandis (Fig.33)is convex. The vascular bundles are single in all of the examined taxa except inTectoniagrandis(Fig.33) in groups. Sclerenchymatous bundle sheath showed inTectoniagrandis only(Fig.33).Secretory cells and secretory cavities are shown in some plants as in Salvia farinacea(Fig.35).Crystals are also noticed in two shapes, rosette crystals, as in Vitexagnus - castus (Fig.36), prismatic crystals as in Tectoniagrandis (Fig.34). Such results were strengthened byOzdemir and Senel (1998) and Satil and Kaya(2007). Who pointed out that the adaxial surface was flat to concave and the abaxial surface was convex shaped vascular bundles were collateral there was one large vascular bundle in the center. 


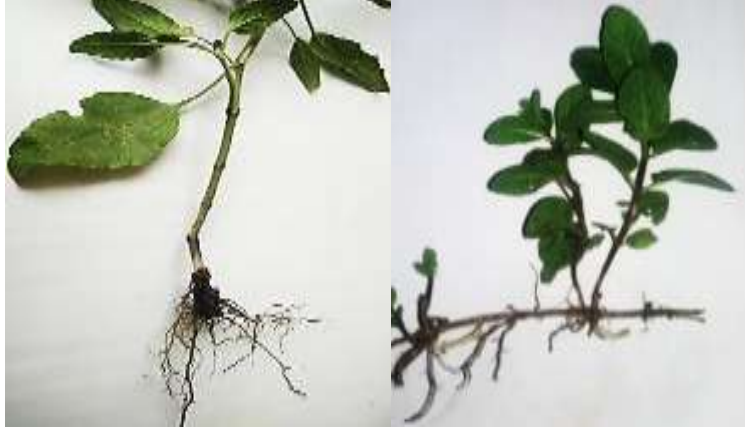

(Fig 1 )

(Fig 2)

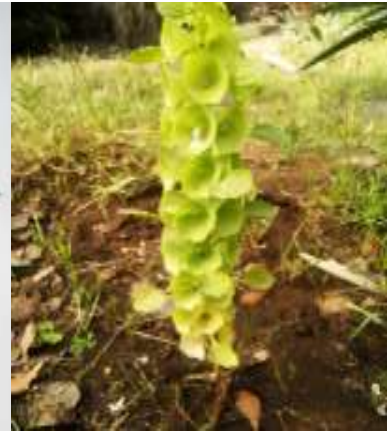

(Fig 3)

Figures: (1 and 2) Show root types:

(Fig1) Tap root inSalvia farinaceaBenth. and (Fig 2 ) Fibrous roots in MenthapiprataL.

(Figure3)unbranched steminMoluccellalaevisL.

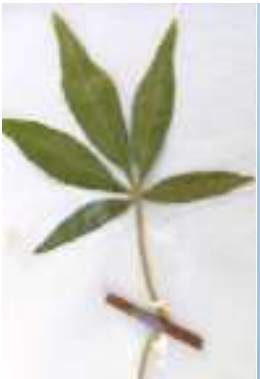

(Fig. 4)

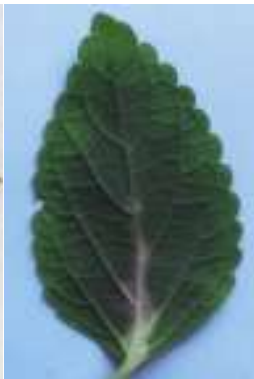

(Fig. 5)

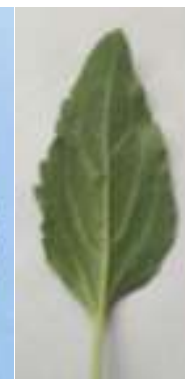

(Fig. 6)

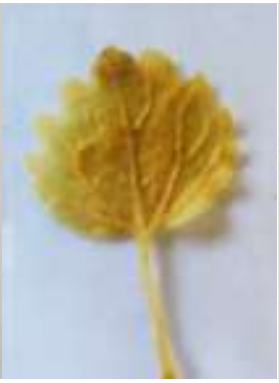

(Fig. 7)

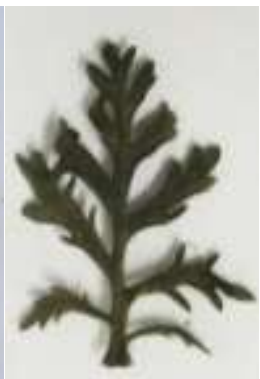

(Fig. 8)

Figures: (4 - 8) Show leaf types:

(Fig. 4) compound palmate inVitexagnus - castusLinn., (Fig. 5) ovate in Coleus blumeiBenth., (Fig. 6) lanceolate in Salvia farinaceaBenth., (Fig. 7) Palmetaly-lobed in Moluccellalaevis L. and (Fig. 8) Pinnatelyloped in LavandulapubesansDecne

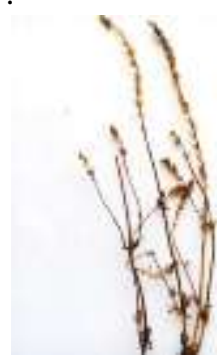

(Fig. 9)

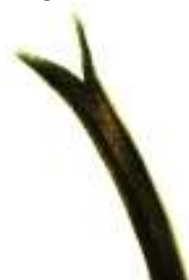

(Fig.16) (Fig. 17)

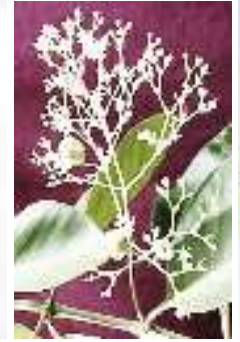

(Fig.10)

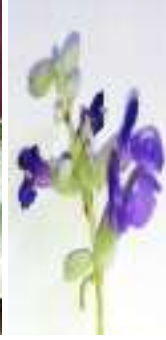

(Fig.11)

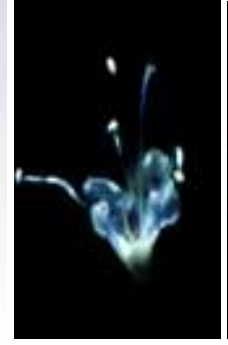

(Fig. 12)

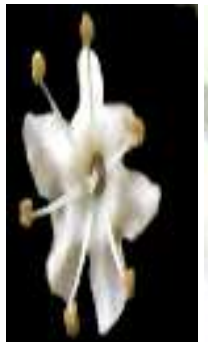

(Fig. 13)

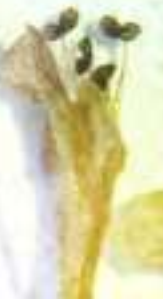

(Fig.14)

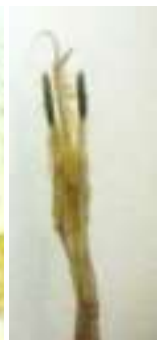

(Fig. 15)

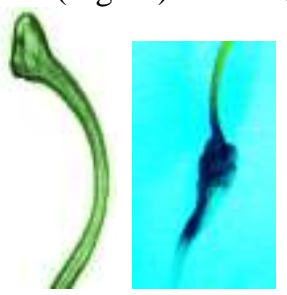

(Fig. 18)

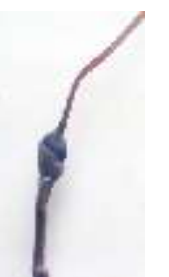

(Fig. 19)

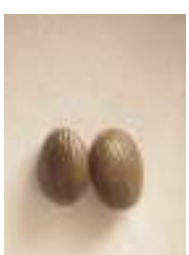

(Fig. 20)

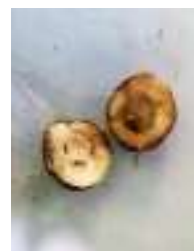

(Fig. 21)

Figures :( 9 and 10) Show inflorescence types: (Fig. 9) simple spike in LavandulapubesansDecne.and (Fig. 10) compound raceme inTectoniagrandis L.

Figures: (11 - 13) Show corolla types:

(Fig. 11) bilabiate in Salvia farinaceaBenth., (Fig.12) 4 equal lobes 2 inMenthapiprataL. and (Fig.13) 6 equal lobes in Tectoniagrandis L.

Figures: (14 and 15) Show stamen number:

(Fig .14) 4 stamensinMoluccellalaevis L. and (Fig. 15) 2 stamens in Salvia farinaceaBenth.

Figures: (16 and 17) Show the stigmashape :

(Fig .16)Linear inMoluccellalaevisL. and (Fig.17) capitatein LavandulapubesansDecne.

Figures : (18 and19) Show style position in: 
(Fig.19) gynobasic in MoluccellalaevisL.and (Fig.20) ungynobasic inVitexagnus - castusL.

Figures : (20 and 21) Show fruit types in:

(Fig.20) nutletsin MoluccellalaevisL. and (Fig.21)droup in Vitexagnus - castusLinn.

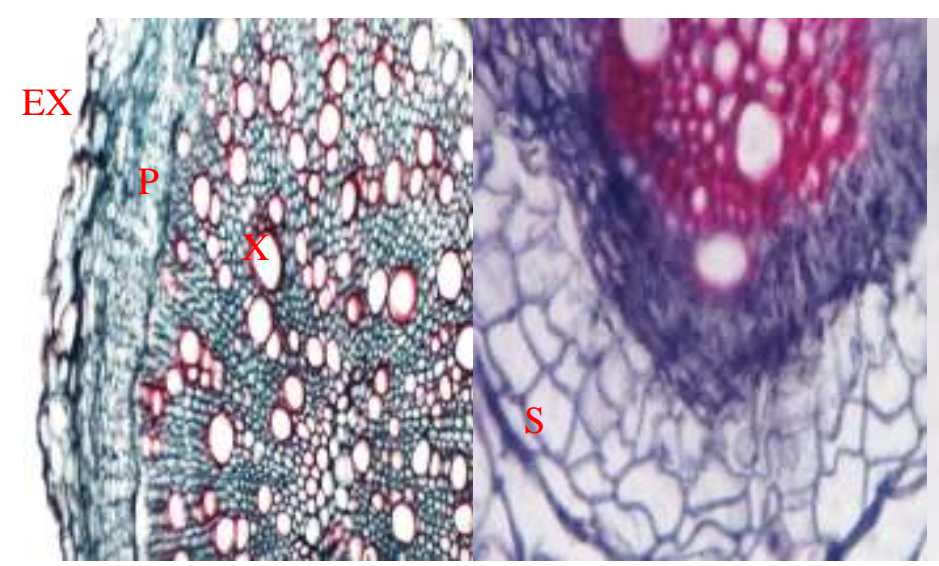

(Fig.22)

(Fig.23)

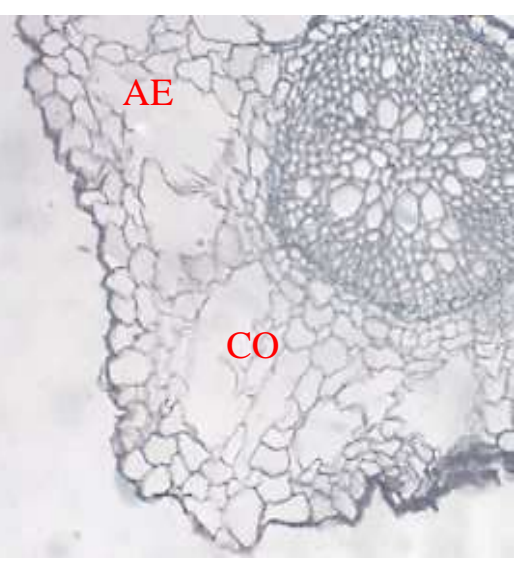

(Fig. 24)

Figures : (22 - 26) Cross section in root of : (Fig. 22)MoluccellalaevisL. (X 400), (Fig. 23)TeucriumpoliumL.(X 400), (Fig. 24) MenthapiprataL. (X 100)

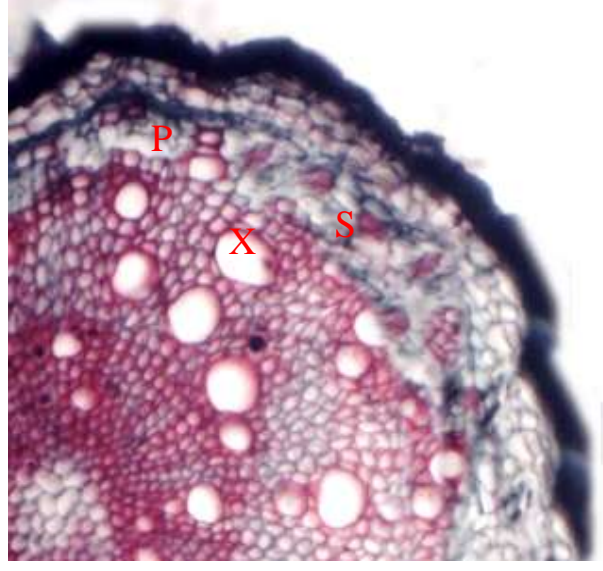

(Fig.25)

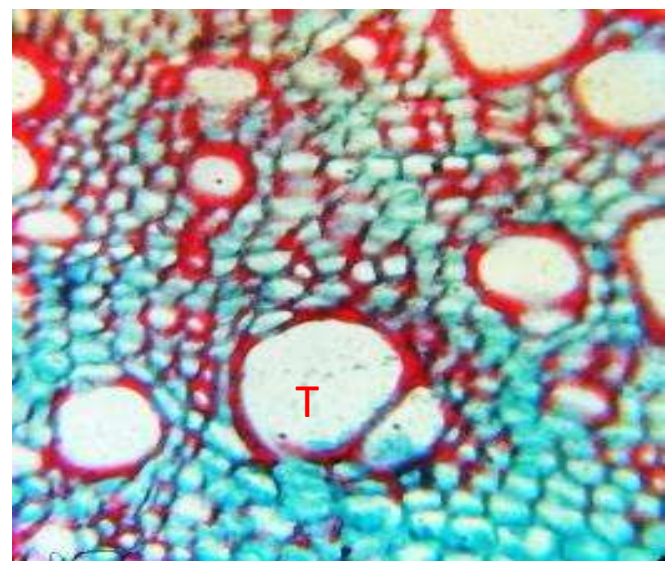

(Fig. 26)

(Fig .25) Salvia farinaceaBenth.(X 100) and (Fig. 26) Coleus blumeiBenth.(X 400).

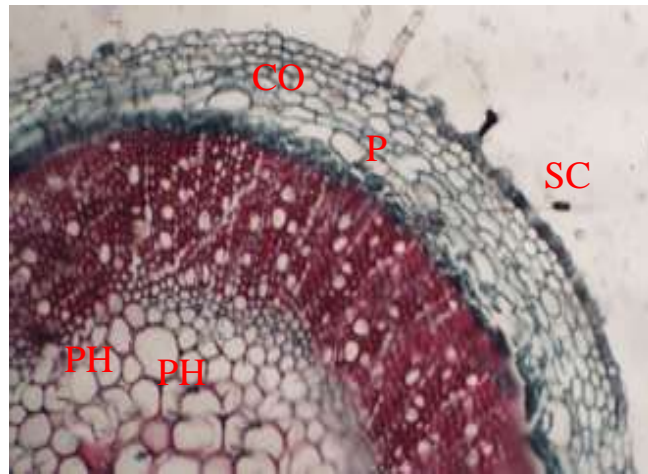

(Fig.27)

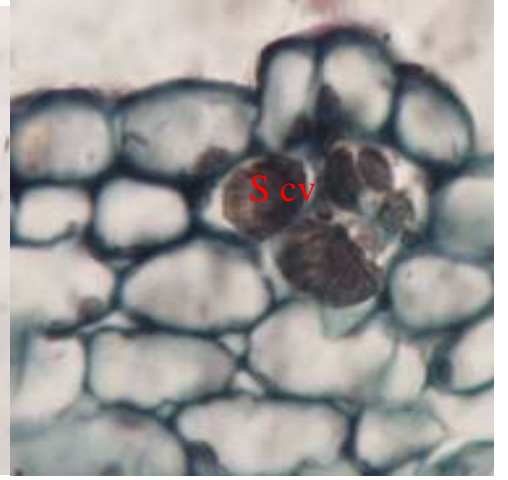

(Fig.28) 


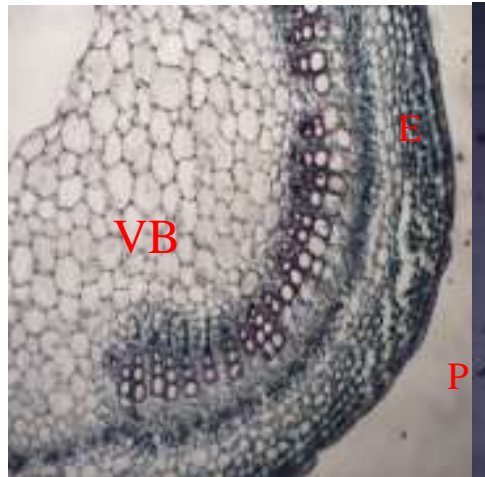

(Fig .29)

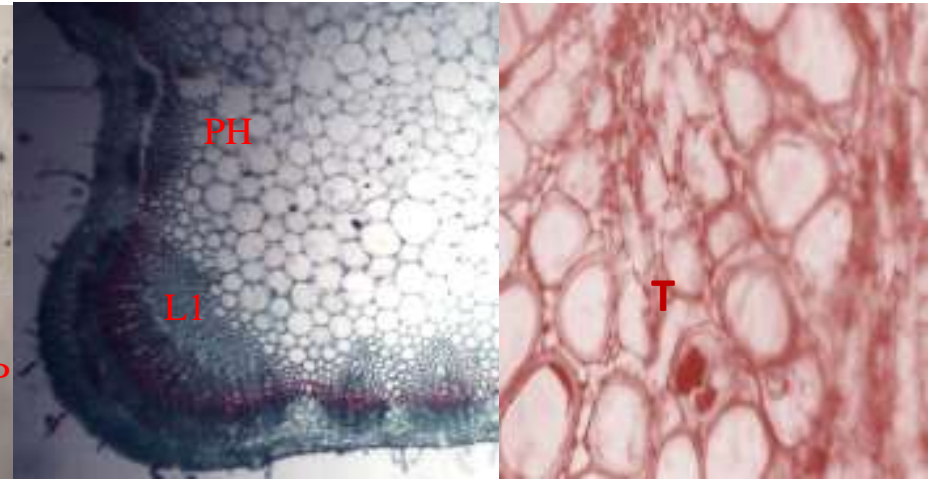

(Fig.30)
(Fig.31)

Figures: (27 - 31) Cross section in stem of: (Fig. 27)TeucriumpoliumL. (X 100), (Fig.28) TeucriumpoliumL. (X 400), (Fig. 29)MoluccellalaevisL. (X 100), (Fig. 30) Salvia farinaceaBenth.(X 100) and(Fig. 31) TectoniagrandisL. (X 400).

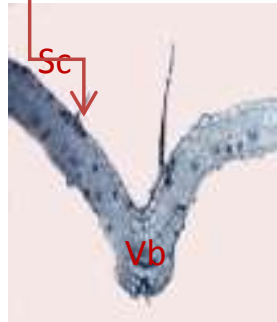

(Fig.32)

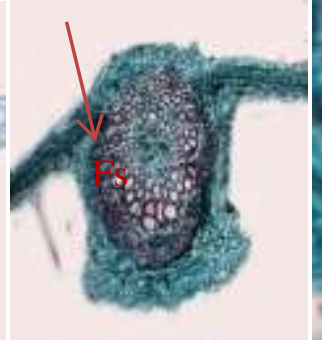

(Fig. 33)

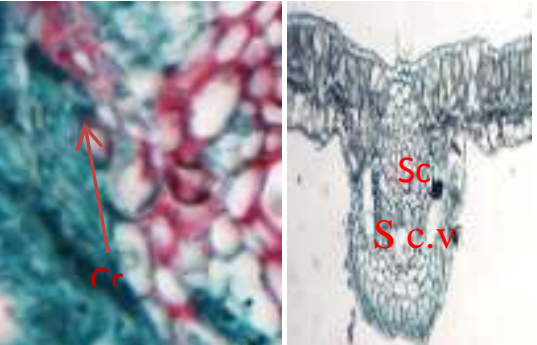

(Fig.34)

(Fig.35)

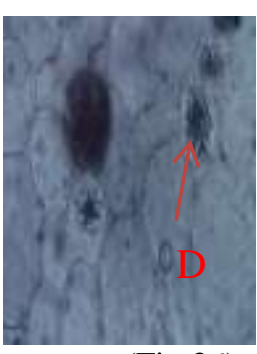

(Fig.36)

Figures: (32 - 36) Vertical section in leaf of:

(Fig.32)TeucriumpoliumL. (X 100),(Fig. 33) TectoniagrandisL.(X 40),(Fig.34) TectoniagrandisL. (X 400), (Fig.35) Salvia farinaceaBenth. (X 100) and (Fig.36) Vitexagnus - castusLinn. (X 400).

From the analysis of the collected results by using the program (MVSP), We canagreement on attach Vitexagnus - castus toLamiaceae, while not can agreement on attachTectoniagrandis toLamiaceae. (MVSP)Multi variate statistical package

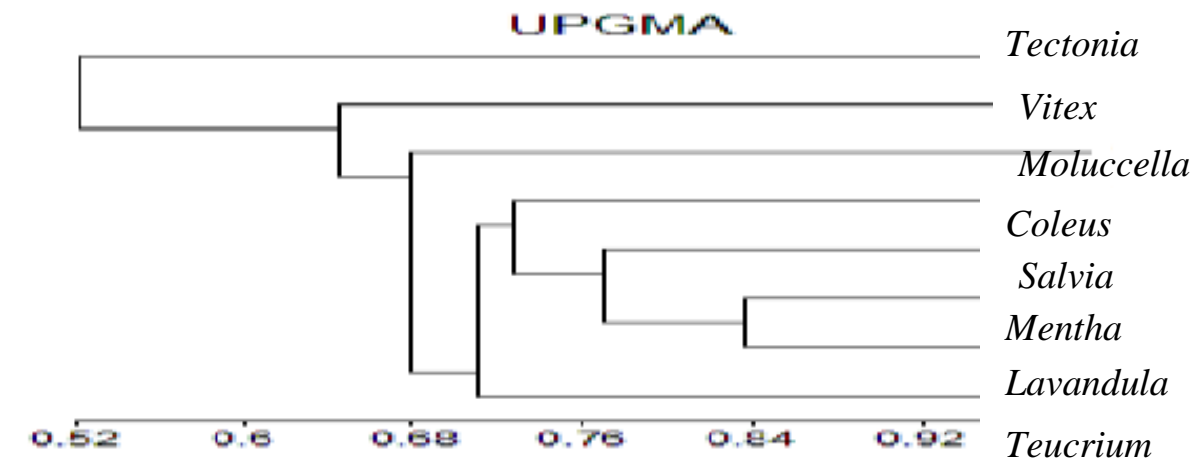

(Figure 37) Dendrogram represent the relationships of similarity among 8 genera or Lamiaceae.

\section{Key of genera}

Annul. 1

perennial.......................................................2

1- I-Stem unbranched; Leaves palmate lobed; Calyx cmpanulate. Moluccella

II-Stem branched; a leaves ovate, crenate, colored Coleus

2- Corolla labiatae 3

Corolla consist of equal lobes 4

3- Corolla labiatae with lower lip only. Teucrium

Corolla bilabiatae with 2 lips.... .5

4- Corolla consist of 4 equal lobes, stamens 4 unequal Mentha. Corolla consist of 6 equal lobes, stamens 6 equal.................... Tectonia

5- Simple leaves ....................................................... 6 Compound leaves; stamens 4 equal 6- Leavespinnately- loped; stamens 4; Stigma capitate Leaves lanceolate; stamens 2 Vitex Lavandula Salvia 
Table 2. List of (50) characters recorded comparatively for (8) genera belonging to Lamiaceae.The characters were distinguished into (44) qualitative, (4) multistate and (2) quantitative.

Qualitative characters:

Morphological characters:

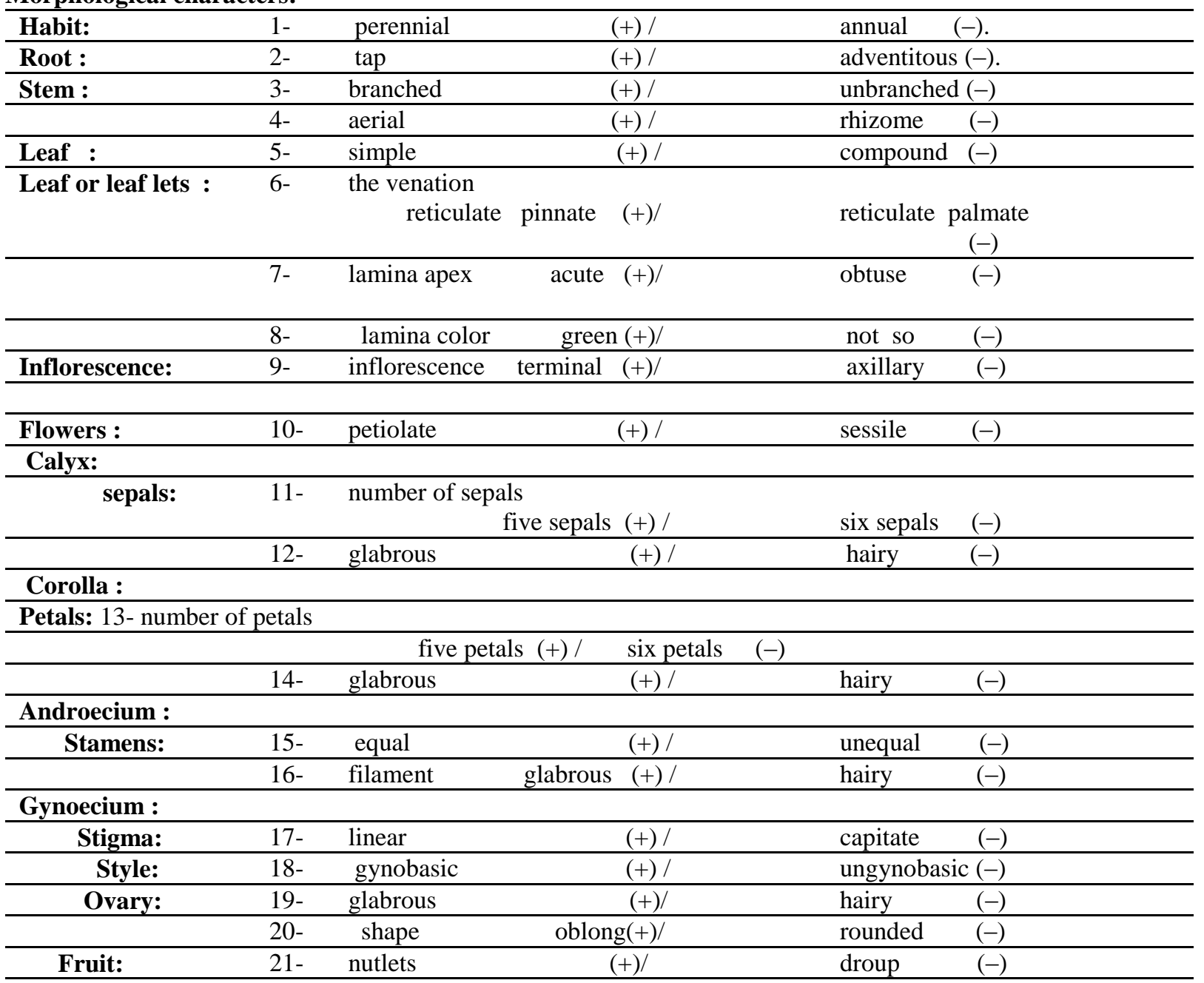

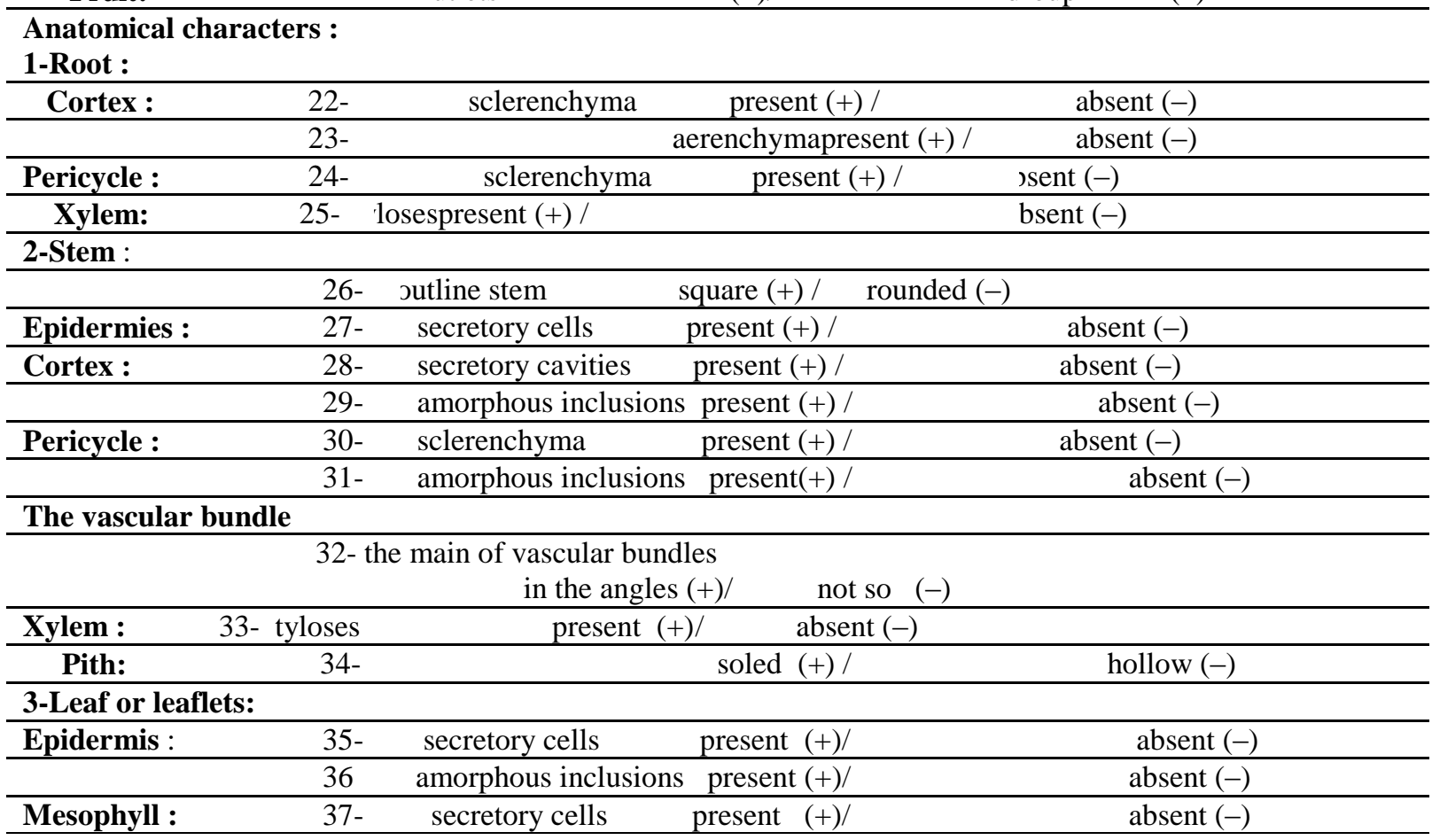




\begin{tabular}{|c|c|c|c|c|}
\hline \multicolumn{5}{|l|}{ Midrib region: } \\
\hline & $38-$ & upper epidermis & concave $(+) /$ & convex $(-)$ \\
\hline & $39-$ & \multicolumn{2}{|c|}{$\begin{array}{l}\text { the vascular bundles inmidrib region, } \\
\text { one }(+) /\end{array}$} & $\begin{array}{c}\text { more than } \\
(-)\end{array}$ \\
\hline & $40-$ & fibers sheath & present $(+) /$ & absent $(-)$ \\
\hline & 41- & secretory cells & present (+) / & $\operatorname{absent}(-)$ \\
\hline & $42-$ & secretory cavities & present $(+) /$ & $\operatorname{absent}(-)$ \\
\hline & $43-$ & druses crystals & present $(+) /$ & $\operatorname{absent}(-)$ \\
\hline & $44-$ & prismatic crystals & present (+) / & $\operatorname{absent}(-)$ \\
\hline
\end{tabular}

Multistate characters:

Morphological characters:

Habit:

45- (3 categories), herbs, 1; shrubs, 2 and trees, 3.

Leaf or leaflets:

46- leaves shape (5 categories), ovate, 1; lanceolate,2; Palmetaly

Palmetaly-lobed,3; Pinnately- loped ,4 and compound palmate, 5.

Inflorescences

47- (3 categories), verticillate, 1 ; simple spike ,2 and compound raceme,3.

Flower:

Corolla :

48-(3categories), bilabiate, 1 ; limb regular of 4 almost equal lobes 2 and limb regular of 6 almost equal lobes.

\section{And roecium :}

Quantitative characters

49- number of stamens.

\section{Gynoecium}

50- length of style in $\mathrm{mm}$.

Table 3. List of (50) characters recorded comparatively for (8) genera belonging to Lamiaceae.The characters were distinguished into (44) qualitative, (4) multistate and (2) quantitative.

\begin{tabular}{|c|c|c|c|c|c|c|c|c|c|c|c|c|c|c|c|c|c|c|c|c|c|}
\hline $\begin{array}{c}\mathrm{Ch} \\
\mathrm{P}\end{array}$ & 1 & 2 & 3 & 4 & 5 & 6 & 7 & 8 & 9 & 10 & 11 & 12 & 13 & 14 & 15 & 16 & 17 & 18 & 19 & & 20 \\
\hline 1 & - & - & + & + & + & + & - & - & + & + & + & + & + & + & - & + & + & + & - & & - \\
\hline 2 & + & + & + & + & + & + & + & + & + & - & + & + & + & + & - & + & - & + & - & & - \\
\hline 3 & + & - & + & \pm & + & + & + & + & + & + & + & + & + & + & - & + & + & + & - & & - \\
\hline 4 & - & + & - & + & + & - & + & + & - & + & + & + & + & + & - & - & + & + & - & & - \\
\hline 5 & + & + & + & + & + & + & + & + & + & + & + & - & + & - & + & + & + & + & - & & - \\
\hline 6 & + & + & + & + & + & + & + & + & + & + & - & + & - & + & + & + & + & - & + & & + \\
\hline 7 & + & + & + & + & + & + & + & + & + & + & + & + & + & + & - & + & + & + & - & & - \\
\hline 8 & + & + & + & + & - & - & + & + & + & + & + & + & + & + & + & + & + & - & - & & + \\
\hline $\begin{array}{c}\mathrm{Ch} \\
\mathrm{P}\end{array}$ & 21 & 22 & 23 & 24 & 25 & & 26 & 27 & 28 & & 29 & 30 & 31 & 32 & 33 & 34 & 35 & 36 & 37 & 38 & 39 \\
\hline 1 & + & - & - & - & + & & + & - & - & & - & - & - & + & - & + & + & + & - & + & + \\
\hline 2 & + & - & - & - & - & & + & - & - & & - & - & - & + & - & + & - & - & - & + & + \\
\hline 3 & + & - & + & - & - & & + & - & - & & - & - & - & + & - & + & - & - & - & + & + \\
\hline 4 & + & - & - & - & - & & + & + & - & & + & - & + & + & - & - & - & - & - & + & + \\
\hline 5 & + & - & - & + & - & & + & - & - & & - & + & - & + & - & + & - & - & - & + & + \\
\hline 6 & - & - & - & - & + & & + & - & - & & - & + & - & + & + & + & - & - & - & - & - \\
\hline 7 & + & + & - & - & - & & - & + & + & & + & - & - & - & - & + & + & + & + & + & + \\
\hline 8 & - & - & - & + & - & & + & - & - & & - & + & - & + & - & + & - & - & - & + & + \\
\hline $\begin{array}{c}\mathrm{Ch} \\
\mathrm{P}\end{array}$ & 40 & 41 & & & 43 & & 44 & & 45 & & & 46 & & 47 & & 48 & & 49 & & 50 & \\
\hline 1 & - & + & & & - & & - & & 1 & & & 1 & & 1 & & 1 & & 4 & & 1 & \\
\hline 2 & - & - & & & - & & - & & 1 & & & 4 & & 2 & & 1 & & 4 & & 3 & \\
\hline 3 & - & - & & & - & & - & & 1 & & & 2 & & 1 & & 2 & & 4 & & 3 & \\
\hline 4 & - & - & & & - & & - & & 1 & & & 3 & & 1 & & 1 & & 4 & & 8 & \\
\hline
\end{tabular}




\begin{tabular}{llllllllllll}
\hline 5 & - & + & + & - & - & 1 & 2 & 1 & 1 & 2 & 3 \\
6 & + & - & - & - & + & 3 & 1 & 3 & 3 & 6 & 3 \\
7 & - & - & - & - & - & 1 & 3 & 1 & 1 & 4 & 4 \\
8 & - & - & - & + & - & 2 & 5 & 1 & 1 & 4 & 5 \\
\hline
\end{tabular}

\section{References}

Akcin,D.E., Senel,G. and Akcin,Y. (2006).The morphological and anatomical properties of Ajugareptans L. and Ajugachamaepitys(L.) schreber subsp. chia (schreber) Arcangelivar.chia (Lamiaceae) taxa. PJBS. Vo. 9(2), 289- 293.

Badamtsetseg, B. (2016). Fruit morphology of some species of the Lamiaceae in the flora of Mongolia .Turczaninowia. Vo.19 (1), 34-41.

Bailey, L. H. (1951). Manual of Cultivated Plants. The macmillancompany.London. PP: 634 - 652.

Baran,P. and Ozdemer ,C. (2006). The morphological and anatomical chara-cters of Salvia napifoliaJacq.in Turkey.Bangladesh J. Bot. Vo. 35(1), 77- 84.

Baran, P., Ozdemir, C., and Aktas, K. (2008). The morphological and anat-omical Properties of Salvia argentea L. (Lamiaceae) in Turkey.Research journal of agriculture and biological Sciences.Vo. 4(6), 725-733.

Boulos , L . (2002). Flora of Egypt . AL hadara publishing, Cairo-Egypt.Vo. 2. PP: $139-143$.

Celep, F., Kahraman , A. , Atalay, Z. , and Dogan, M. (2011).Morphology, anatomy and trichome properties of LamiumtruncatumBoiss.(Lamiaceae) and their systematic implications.AJCS.Vo.5(2), 147-153.

Chase, M., Bremer, B., Bremer, K., Soltis, E.D., and Stevens, F.P. (2003). Update of the Angiosperm phylogeny Groups.Classfication for the ord-ers and Families of Flowering plants:APG11. Botanical.JLS.399 -436.

Chaker, A.N., Boukhebti,H., Sahli,F., Haichour,R and Sahraoui,R.(2011).Morpho-logical and anatomical study of two medicinal plants from genus Mentha.AEB. Vo. 5(2), 219-221.

Cronquist,A.(1981) : An Integrated System of Classification of Flowering plant. Clum- bia university press P.371.
EL-Gazzar,A. and Watson, L.(1970). A taxonomic study of Labiata and related genera. New Phytol. Vo. (69), 451-486.

Hickey, M. and King, C. J. (1988).100 Families of floweringplants.Cambridge Unive.

Press. PP: 350- 355.

Kotb, F. (1985).Medicinal Plants in Libya.Arab encyclopedia house.Vo. (1)170. PP: 338, 536,744, 786 and 816.

Metcalfe,C.R. and Chalk,L.(1950).Anatomy of the Dicotyledons.ClerendonPress, Oxford. Vol .1.684 $-691$.

Migahid, A. $M$ and Hammouda, $M$. A.(1974).Flora of Saudi Arabia.publication by Riyad University. PP: 290 - 294.

Ozdemir,C. and senel,G. (1998).The morphological, anatomical and karyological Properties of Salvia sclareaL. Tr. J. of Botany .Vo. (23).7-18.

Sass, J. E. (1958).Botanical microtechnique .The Iowa State university press. Iowa. PP: 228.

Satil,F. and Kaya, A.(2007). Leaf anatomy and hairs of Turkish Satureja L.(amiaceae).Acta Bio.CracoviensiaSer. Bot. Vo.49(1). 67-76.

Tackholm, V. (1974). Student's Flora of Egypt. Ed.2 Cairo Unive. Book shop. Cairo. PP: 93 - 98.

Waly, N.M. and EL-Gayed, S.H.(2012).Botanical and biological studies oflectranthustenuiflorus(vatke) agnew. (lamiaceae) growing in Saudi Arabia. Inter.Jou.of life sc. Vo. 2. $52-64$.

Watson, L. and Dallwitz, M.J.(1992).The families of flowering plants. descriptions, illustrations, identification and information retrieval. <www.delta-intkey.com>.

Wendy, B. Z. (1994).Plant Families. University of North Carolina press Chapel Hill \& London. PP: 121-123 


$$
\begin{aligned}
& \text { دراسات نباتية مقارنة علي بعض النباتات الثفويه فى مصر }
\end{aligned}
$$

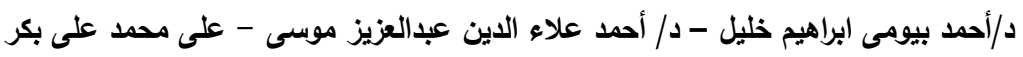

$$
\begin{aligned}
& \text { قسم النبات الزراعي - كلية الزراعة - جامعة الأزهر - القاهرة } \\
& \text { الملخص العربي }
\end{aligned}
$$

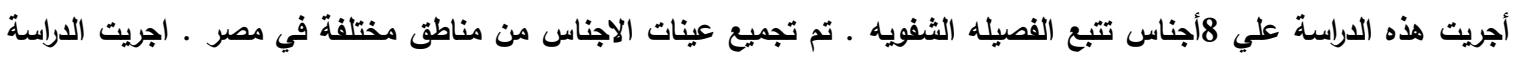

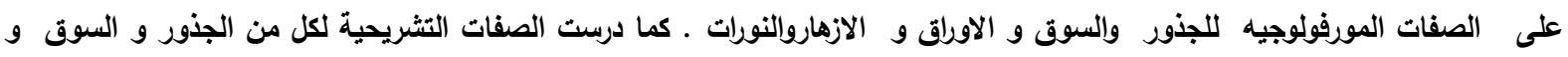

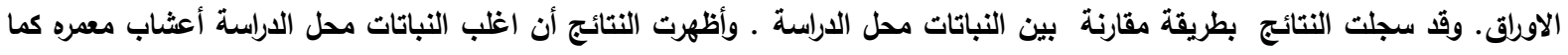

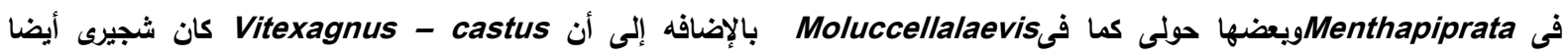

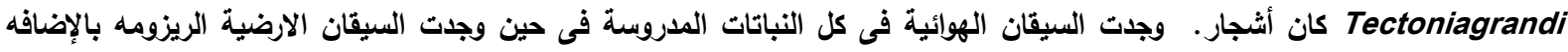

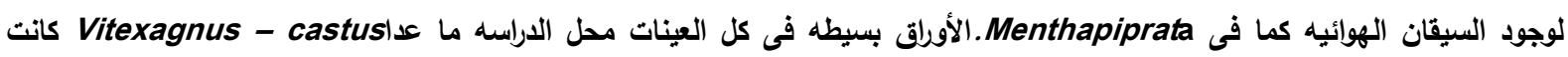
مركبه راحيه. الأسديه كانت4 أسديه فى معظم النباتات ما عدا SSalvia farinacea كانت سداتين ، Tectoniagrandis كانت 6 أسديه.

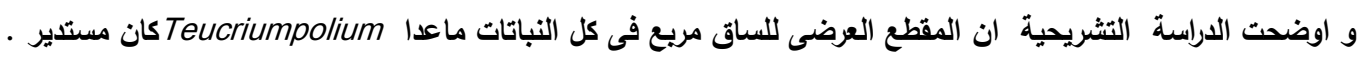
ومنتحليل النتائج المتحصل عليها من الدراسة باستخدام برنامج (ChSP نستخلص أنه يمكن الإتفاق مع (Chase et al 2003 ) على في ضم Vitexagnus - castus إلى الفصيله الثفويهبينما يجب إعادة النظر فى ضم Mectoniagrandis 